TURKEY, ISLAM, NATIONALISM, AND MODERNITY 


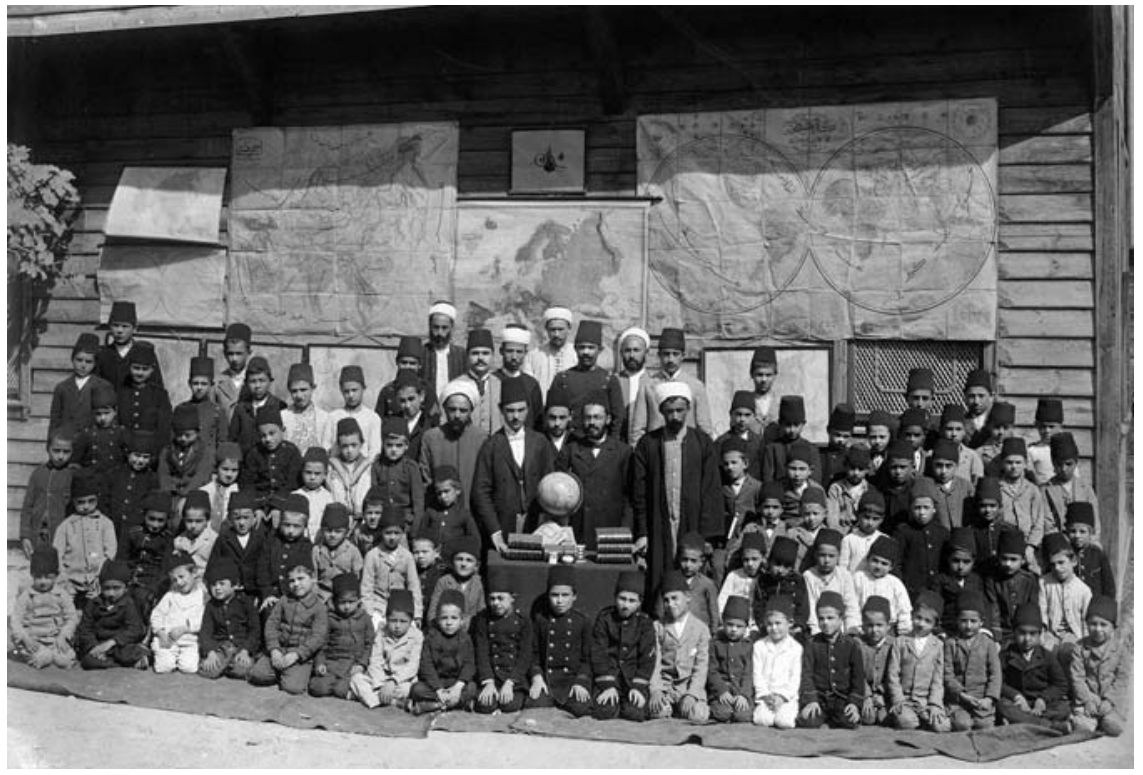




\section{TURKEY, ISLAM,}

Nationalism, AND

MODERNITY

A History, 1789-2007

Carter Vaughn Findley

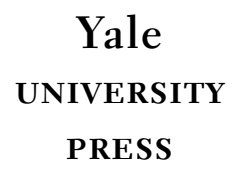

New Haven E London 
Published with assistance from the Louis Stern Memorial Fund.

Copyright (C) 2010 by Yale University.

All rights reserved.

This book may not be reproduced, in whole or in part, including illustrations, in any form (beyond that copying permitted by Sections 107 and 108 of the U.S.

Copyright Law and except by reviewers for the public press), without written permission from the publishers.

Yale University Press books may be purchased in quantity for educational, business, or promotional use. For information, please e-mail sales.press@yale.edu (U.S. office) orsales@yaleup.co.uk (U.K. office).

Set in Postscript Electra type by diacriTech

Printed in the United States of America.

Library of Congress Cataloging-in-Publication Data

Findley, Carter V., 1941-

Turkey, Islam, nationalism, and modernity / Carter Vaughn Findley.

p. $\mathrm{cm}$.

Includes bibliographical references and index.

ISBN 978-0-300-15260-9 (clothbound : alk. paper) 1. Turkey-History-19th century.

2. Turkey-History-2oth century. 3. Turkey-Politics and government-19th century.

4. Turkey-Politics and government-2oth century. 5. Nationalism-Turkey-History-19th century. 6. Nationalism-Turkey-History-2oth century. 7. Secularism-Turkey-History19th century. 8. Secularism-Turkey-History-2oth century. 9. Islam and state-Turkey-

History-19th century. 10. Islam and state-Turkey-History-2oth century. I. Title.

$$
\begin{gathered}
\mathrm{DR}_{557} \cdot \mathrm{F}_{5} 6_{2010} \\
956.1-\mathrm{dc}_{22} \quad 2010013169
\end{gathered}
$$

A catalogue record for this book is available from the British Library.

This paper meets the requirements of ANSI/NISO Z39.48-1992 (Permanence of Paper).

$$
10987654321
$$

Frontispiece: An Ottoman school, 1885, site for the expansion of literacy that made possible the rise of print media. The teachers include both ulema (in turbans) and non-ulema (in fezes). The globe, books, and maps proclaim the school's modernity.

(By Sebah and Joaillier, 1885; courtesy of Pierre de Gigord.) 
For my children

Madeleine Vaughn Findley

and

Benjamin Carter Findley 
This page intentionally left blank 